\title{
Corporate Governance and Performance of Indian Companies: Case Study
}

\author{
*Dr. Ch. Sudipta Kishore Nanda \\ *Assistant Professor, School of Commerce, Ravenshaw University, Cuttack, Odisha,India,
}

\begin{abstract}
Corporate Governance is considered to have significant implications for the growth prospects of an economy. Good Corporate Governance practices are regarded as important in reducing risk for investors, attracting investment capital and improving the performance of the firms. However, the way in which corporate governance is organized differs between countries, depending on their economic, political and social contexts. Given the importance of the research problem to the field of corporate finance and for resolving the inconsistent research findings in the prior literature, the co relation between individual governance mechanism and performance of firms have been looked into.

The study made an attempt to focus on five years data from 2006-2010 but due to non-availability of data of 5 years for all the companies finally the study could include only 163 companies from the BSE 200 list. The purpose of this research paper was to examine the relationship between individual corporate governance mechanism and performance of Indian companies. A correlation matrix has been presented to describe the linear relationship between five governance facets and six performance variables.
\end{abstract}

Keywords: Corporate Governance, Performance, Governance mechanism

\section{Introduction}

Corporate Governance is the set of processes, customs, policies, laws and institutions affecting the way a corporation is directed or controlled. Corporate Governance also includes the relationships among the many participants involved and goal for which the corporation is governed. In this regard, corporate governance has succeeded in attracting a good deal of public interest because of its importance for the economic health of corporations and society in general. However the concept of corporate governance has been considerable interest in the corporate governance practices of modern corporations, particularly the high profile collapses of firms such as Satyam, Enron Corporation etc.

The question of corporate governance in India has come mainly in the wake of economic liberalization, deregulation of industry and business as also the demand for a new corporate ethos and stricter compliance with the legislation. The new economic policies adopted by the Government of India since 1991 has necessitated the demand for introduction and implementation of a proper corporate governance policy in management of companies not only in the interests of their stakeholders but also for the overall development of the country.

There has been considerable research in the domain of corporate governance in recent years in India. In the light of the growing importance of India in the world economy as a source of intellectual capital and outsourcing possibilities, there is an urgent need to understand the governance structures in India India's cultural values are different from other countries values, are shaped by history and institutions and form the backdrop of businesses in a country. The dynamism of these influences in India has resulted in a complex blend of ownership forms that include family governance, professional and foreign owned firms. The corporate governance also has to take into account the legal, regulatory, institutional and ethical environment of the community. Corporate success and sustainable economic growth rest with good governance. A firm which has good governance system has better image and greater value, higher profits and higher sales growth than those with poor governance system (Paul et al. 2003). Furthermore, corporate governance will promote enterprise and ensure accountability. Different countries follow different models of corporate governance depending upon their environment, cultural background etc. The importance of corporate governance had not been felt and practice in the past until the economic crisis hit many parts of the western and Asian countries. The current wave of reform of Corporate Governance commenced with the Cadbury code of practice published by the London Stock of Exchange in 1992. Corporate Governance has now become the subject of intense debate in the background of the recent scam involving the world's leading firms that include Enron, WorldCom, Xerox and others and has become a mainstream issue and subject of discussion for boardroom, academics circles, government and regulators. These incidents highlighted the importance and status of corporate governance the world over.

In effectual, poor corporate structure increase the risk of fraud, corporate failure or both. Further, with the wave of globalization, mergers and acquisition, there is an increasing competition where only the strong survive, brought the corporation towards better governance system. Corporate Governance concerns the exercise of power in corporate entities and has wider implications and is critical to economic and social well-being, 
firstly in providing the incentives and performance measures to achieve business success, and secondly in providing the accountability and transparency to ensure the equitable distribution of the resulting wealth. Thus the quantity, quality and frequency of financial disclosure, accountability, transparency in corporate functioning for maximizing shareholders wealth are the progressive elements and indeed the underlying spirit of corporate governance. Failure in Corporate Governance is a real threat to the future of every corporation and to the economy, therefore the weakness of corporate should be tackle and assess for healthy future.

\section{Literature Review}

Brown, Robinson, Caylor (2004), study the linkages between Corporate Governance to Firm Performance using 2,327 firms based on 51 corporate governance provision provided by Institutional Investors Services (ISS) and using Pearson and Spearman correlation analysis finds that firms with poor governance are relatively less profitable and less valuable. Further they find that executive and director compensation are highly associated with good performance while governance category, charter/by laws, is least associated with good performance.

Johnson, Boone, Breach, Friedman (2000) study whether the weakness of legal institutions for corporate governance had an important affect on the extent of depreciation and stock market declines in the context of Asian countries during the crisis. Taking a sample of 25 firms of emerging markets and using regression co-efficient analysis finds that managerial agency problems can make countries with weak legal system vulnerable to loss of investor confidence that results in fall in asset value and decline in exchange rate. They find that corporate governance variables affect more variation in exchange rate and stock market performance than macroeconomic variables.

Todd Milton (2004), in his study on corporate governance and dividend policy in emerging market, with a sample of 365 firms from 19 countries found that firms with stronger corporate governance have higher dividend payout and also there is an increase negative relationship between dividend payout and growth opportunities. Moreover, firms with stronger governance show higher profits. The study also reveals that countries with stronger investor protection have a limitation of dividend payout. Further, country level investor protection and firm level corporate governance are complementary to each other. (Shareholder prefers higher dividend paid when the firm has weak legal protection and vice versa. CG rating developed by credit Lyonnais securities Asia, CLSA-2001 is used.)

Bernard Black (2001), in his study on the relationship between CG behavior and market value of Russian firm took a sample of 21 Russians firms. The study reveals that CG behavior has a strong impact/effect on the market value in a country where legal and cultural constraint on corporate behavior is weak. According to the reports of World Bank, Public corporations in East Asia typically have low levels of transparency and disclosure quality. Some commentators and policy advisors believe that a closer adherence to international disclosure rules and the adoption of international accounting standards are essential for improving corporate transparency in the region (World Bank, 1998, East Asia).

Jayanth R. Varma (2002) studies and documents the accounting scandals and corporate frauds that came to light during 2001 and 2002 of Enron and other companies in the United States and elsewhere. It then describes the failure of governance and supervision as well as the failure of market discipline that took place and go on to analyze the lessons that can be drawn from these episodes. He concluded that while the Enron and related scandals represent a massive regulatory failure those failures are inherent in the regulatory process. Regulators are poor at detecting fraud, and therefore suggest that market discipline should be strengthened. Further the study also suggest four important measures: encouraging hostile take-over, allowing free short selling, permitting and facilitating class action lawsuits, and promoting competition in the securities industry.

Joh, (2003) study the affect of poor corporate governance system on firm profitability in the context of Korean firms before the crisis and also investigate whether other factor also contribute to poor performance. Using a data of 5829 Korean firms for the period 1993-1997 in which firm profitability was measure through its performance by using accounting profitability and regression analysis while controlling industry fixed effect. He concluded that poor corporate governance and weak legal environments prevails even before the crisis that contribute for poor firm performance besides this lower controlling by family ownership and financial investment in affiliated firm also effects firm profitability. Firms with higher control- ownership disparity showed lower profitability. Back, Kang \& Park (2004) study the effect of corporate governance on firm performance during Korean crisis (1997), using a sample of 644 non- financial listed on the Korean Stock exchange between November 1997-December 1998 and using a statistical regression analysis, they concluded that firms with larger equity ownership by foreign investors experience a smaller reduction in their share value. Firms that have higher disclosure quality and alternative sources of external financing also suffer less and affiliated firms also exhibits larger drop in equity value. Firms that have higher cash flow than the voting rights and those that borrow more from the bank has lower returns and similar effects on diversified firms, those with high leverage and those that are small and risky. They also find that agency problem between controlling 
shareholders and minority shareholders is much serious during the crisis and concentrated ownership has strong incentives to maximize either their own utility or overall size rather than individual firms. Klapper \& Love (2004) investigate the determinants of firm-level governance, their relationship with the country legal environments and the correlations between governance and performance taking data from 495 firms in 25 countries. Using Tobin Q'(as a market valuation of the firm) and Return on Assets(ROA) as a measure of operating performance finds that governance is higher in countries with stronger legal protection(using three legal efficacy measures-judicial effiency, antidirectors rights and legality), however there is no systematic relationship between variation in firm level ranking and country legal-efficiency.

Drobetz et.al., (2004) tried to find evidence for a possible relationship between corporate governance and firm performance within a single jurisdiction. Rather than looking at the regulatory environment or ownership structure that effects all firms within a country they focus on the relationship between a large set of governance proxies and firm performance in German public listed firms. To measure the relationship, they use corporate governance rating as a proxy for firm level governance quality and found that C.G is highly correlated with better operating performance, higher stock return and higher valuation. For investigating expected stock return, Historical return and dividend yields $(\mathrm{d} / \mathrm{p} 2)$ of 50 months is used and for C.G and firm valuation Tobin $\mathrm{Q}$ and Market -to-book-ratio is used and find that expected stock return are negatively correlated with firm level.

Fama and Jensen (1983) suggest that the board has no important function of alleviating agency costs that arise from the separation of ownership and decision control in corporattions. Short et el (1999) also take this view and argue that the board of directors is the central corporate governance control mechanism responsible for monitoring the activities of managers. Jensen (1993) describes the board of directors as the apex of the internal control system in an organisation. Therefore, the board of directors exists to protect the interests of shareholders from where it receives its authority for internal control from the stakeholders (Jensen, 1993).

Prior study explains that board size is an important aspect of effective corporate governance (Pearce and Zahra, 1992, Jensen, 1993, Yermack, 1996) and is related to firm performance (Haniffa and Hudaib, 2006). A larger board is more likely to have a greater range of expertise to monitor the actions of management effectively, which is required not only for enhancing the monitoring activities of managers (Monks and Minow, 1995). On the contrary, however, others (Lipton and Lorsch, 1992; Yermack, 1996) argue that a small board is more effective. They argue that large boards may be less cohesive and slow in making decisions. , less candid in discussions of managerial performance and more difficult to coordinate (Lipton and Milliken, 1999). Jensen 1993 argues that large boards are less likely to function effectively and are easier for the CEO to control.

Empirically, the evidence on the importance of board size on firm performance is mixed. Holthausen and Larcker ( 1993) consider board size among other variables that are more likely to influence firm performance. They fail to detect consistent evidence of a relationship between board size and firm performance.Yermark (1986) ; Haniffa and Hudaib ( 2006 ) in their study by using Tobin's Q as a measure of firm performance find in inverse relationship, suggesting that small boards of directors are more effective. In their research study, they argue that whilst the market may percieve large boards as ineffective, they are beneficuially to the company as they provide the diversity of knowledge that is necessary for directing the operations of the company.

Fama and Jensen ( 1983); Shivdasani (1993) also suggest that NEDs are more unlikely to collude with executive directors to expropriate shareholder wealth. In addition, NEDs have incentives to develop reputations as experts in decision control and are concerned about maintaining their reputation because the external labour market prices them according to their performance as NEDs. Moreover, Haniffa and Hudaib (2006) says that, the presence of NEDs on board ensures that executive directors are not the sole evaluators of their performance and thus improving transparency. This literature suggests that a higher proportion on non executive directors on the board improves the ability of the board to monitor managerial performance. However, other literature Demb and Neubauer, 1992; Patto and Baker, 1987 argues that a higher proportion of NEDs may also be detrimental. They may stifle strategic actions, lead to excessive monitoring of managers, lack business knowledge to make them effective and lack real independence to influence the CEO

Lins (1996) shows that companies with a higher proportion of NEDs are more likely to participate in major restructuring events such as mergers, takeovers and tender offers. Weisbach (1998) documents that board with higher proportion of NEDs are more likely to remove poor performing CEOs. Rosenstein and Wyatt (1990) reveal an increase in shareholder wealth following the addition of NEDs to the board. Size and independence of the board cannot in themselves lead to its effectiveness in the monitoring role unless it is diligent or active. Board diligence is an important characteristics for its effectiveness (Kalbers and Fogarty 1993) suggest that the frequency of meetings can be a proxy of diligence. Vafeas (1999) study suggest that the frequency of board meetings is a proxy for the time directors spend monitoring managerial performance. Lipton and Lorsch (1992) suggest that board meeting time is an important resource in stirring the company to better performance. Thus boards that meet more frequently allow directors more time to confer, set strategy and to execute their monitoring role more effectively (Vafeas , 1999). Abbott et el (2003)suggest, when boards hold regular 
meetings they are more likely to remain informed and knowledgeable about relevant performance of the company leading them to take or influence and direct the appropriate action to address the issue.The preceeding discussion suggest that board that meet more frequently are more likely to perform better their roles of monitoring performance in accordance with shareholder's interests. Empirically, the evidence is inconclusive. Vafeas (1999) find that firms with boards that meet more frequently are valued less by the market as reflected in lower Tobin's Q ratioand suggests that the market may perceive more board meetings as expensive in terms of managerial time, travelling expenses and director's meeting fees. However Vafeas (1999) also find that boards meet more frequently after crises and thus improving the company's performance.

\section{Objective of The Study}

The relations between governance and performance of firms have been looked into with help of the following objectives:

$>$ Examining the association between governance practices at firm level with their respective performance

$>$ Identifying the cause and effect relationship between individual governance mechanism (Board process and structure, Ownership structure, Audit committee, Remuneration committee and grievance committee) and the firm performance.

For carrying out the above objectives, the corporate governance information relating to Board of directors, ownership structure, Audit committee, Remuneration committee and grievance committee and their financial statements are collected through secondary source. Different performance measures spread across three categories: operating performance, market value added and shareholder payout are used in the study. Operating performance would be measured through return on equity, profit margin and sales growth. To represent the market value added, the study used P/B ratio that are collected from the website of Bombay Stock exchange. $\mathrm{P} / \mathrm{B}$ is in fact the single MVA measure considered by economics, finance and law researchers. Further the performance measures like EBITDA margin, ROE, Sales growth are collected from the PROWESS (CMIE) data base.

Dividend payout ratio is also considered in the study. Several theories have been put forward to explain the information that dividend pay-out might convey, most prominently the cash flow signaling and the free cash flow hypotheses. The free cash flow hypothesis asserts that the value of the firm should increase if over-investing managers pay out more of the cash flows as dividends. Positive abnormal returns in case of dividend increases and negative abnormal returns in case of dividend reductions are also expected according to the cash flow signaling hypothesis, however. Hence dividend pay-out ratio is used as a proxy for future expected performance of firms. The information on dividend payout ratios for different companies is gathered from the PROWESS (CMIE) data base.

BSE 200 companies representing different size across industries are to be considered for the study as more than that would have been difficult to manage for a clinical exploration. The companies chosen are listed in BSE irrespective of their boundaries confined to India or abroad. The study made an attempt to focus on five years data from 2006-2010 but due to non-availability of data of 5 years for all the companies finally the study could include only 163 companies from the BSE 200 list.

\section{Analysis \& Interpretation}

To investigate the relationship between facets of corporate governance and six different performance variables and to draw reliable conclusion, a multivariate regression framework is used. Table 1.1 through Table 1.5 reports our examination of the main effects of the explanatory variable (i.e. facets of corporate governance) on six different dependent variables (i.e. firms' performance measures).

Individual Governance components on P/B ratio - Impact and Analysis

Table 1.1 Impact of Individual Governance components on $\mathrm{P} / \mathrm{B}$ ratio

\begin{tabular}{|c|c|c|c|c|}
\hline \multicolumn{5}{|c|}{ Dependent Variable: PB } \\
\hline \multicolumn{5}{|c|}{ Method: Panel Least Squares } \\
\hline \multicolumn{5}{|c|}{ Sample: 20062010} \\
\hline \multicolumn{5}{|c|}{ Cross-sections included: 163} \\
\hline \multicolumn{5}{|c|}{ Total panel (balanced) observations: 815} \\
\hline Variable & Coefficient & Std. Error & $\mathrm{t}$-Statistic & Prob. \\
\hline $\mathrm{C}$ & 9.380825 & 4.047772 & 2.317528 & $0.0207 * *$ \\
\hline $\mathrm{BO}$ & -0.76126 & 0.251743 & -3.02395 & $0.0026^{*}$ \\
\hline OW & 0.404607 & 0.136967 & 2.954039 & $0.0032 *$ \\
\hline $\mathrm{AC}$ & 0.286133 & 0.257648 & 1.110558 & 0.2671 \\
\hline $\mathrm{RC}$ & 0.121282 & 0.084634 & 1.433007 & 0.1522 \\
\hline $\mathrm{CG}$ & -0.21153 & 0.067649 & -3.12695 & $0.0018 *$ \\
\hline R-squared & 0.022646 & \multicolumn{2}{|c|}{ Mean dependent var } & 5.443399 \\
\hline Adjusted R-squared & 0.016606 & \multicolumn{2}{|c|}{ S.D. dependent var } & 9.370876 \\
\hline S.E. of regression & 9.292744 & \multicolumn{2}{|c|}{ Akaike info criterion } & 7.30368 \\
\hline
\end{tabular}

DOI: $10.9790 / 487 \mathrm{X}-1809040111 \quad$ www.iosrjournals.org 
Corporate Governance and Performance of Indian Companies: Case Study

\begin{tabular}{|l|l|l|l|}
\hline Sum squared resid & 69861.28 & Schwarz criterion & 7.338304 \\
\hline Log likelihood & -2970.25 & Hannan-Quinn criter. & 7.316969 \\
\hline F-statistic & 3.749073 & Durbin-Watson stat & 1.055416 \\
\hline Prob(F-statistic) & 0.002315 & & \\
\hline
\end{tabular}

* and $* *$ indicate significance at $1 \%$ and $5 \%$ level of confidence.

Table 1.1 reports the analysis of the impact of the five different constituents of corporate governance on Price to Book value ratio. It can be observed that the relationship between Price to Book and Board, Ownership and Governance committee are significant showing significant predictive power at 5\% and $1 \%$ level of significance. A negative correlation between firm value and the size of a firm's board of directors supporting the previous studies by Yermack's (1996) who studied of Fortune 500 industrial firms, partly confirmed by Bhagat and Black (1996).

However, the model lacks predictive power with adjusted R-squares is $2.2 \%$.

Individual Governance components on EBITA Margin - Impact and Analysis

Table 1.2 Impact of Individual Governance components on EBITA Margin

\begin{tabular}{|c|c|c|c|c|}
\hline \multicolumn{5}{|c|}{ Dependent Variable: EM } \\
\hline \multicolumn{5}{|c|}{ Method: Panel Least Squares } \\
\hline \multicolumn{5}{|c|}{ Sample: 20062010} \\
\hline \multicolumn{5}{|c|}{ Cross-sections included: 163} \\
\hline \multicolumn{5}{|c|}{ Total panel (balanced) observations: 815} \\
\hline Variable & Coefficient & Std. Error & t-Statistic & Prob. \\
\hline $\mathrm{C}$ & 43.93216 & 12.20286 & 3.600154 & $0.0003^{*}$ \\
\hline $\mathrm{BO}$ & 1.807627 & 0.758933 & 2.381801 & $0.0175^{*}$ \\
\hline OW & -0.21683 & 0.412916 & -0.52513 & 0.5996 \\
\hline $\mathrm{AC}$ & -2.21756 & 0.776735 & -2.85497 & $0.0044^{*}$ \\
\hline $\mathrm{RC}$ & 0.2993 & 0.255148 & 1.173043 & 0.2411 \\
\hline $\mathrm{CG}$ & 0.056285 & 0.203941 & 0.275985 & 0.7826 \\
\hline R-squared & 0.019163 & \multicolumn{2}{|c|}{ Mean dependent var } & 37.59837 \\
\hline Adjusted R-squared & 0.013101 & \multicolumn{2}{|c|}{ S.D. dependent var } & 28.20026 \\
\hline S.E. of regression & 28.01493 & \multicolumn{2}{|c|}{ Akaike info criterion } & 9.510687 \\
\hline Sum squared resid & 634932.5 & \multicolumn{2}{|c|}{ Schwarz criterion } & 9.545311 \\
\hline Log likelihood & -3869.61 & \multicolumn{2}{|c|}{ Hannan-Quinn criter. } & 9.523976 \\
\hline F-statistic & 3.161089 & \multicolumn{2}{|c|}{ Durbin-Watson stat } & 0.057225 \\
\hline Prob(F-statistic) & 0.007813 & & & \\
\hline
\end{tabular}

$*$ and $*$ indicate significance at $1 \%$ and $5 \%$ level of confidence.

Table 1.2 presents analysis of the impact of five governance variables on firms' EBITA margin. Board and Remuneration Committee share a positive and significant predictive relationship with firms' EBITA margin. But audit committee negatively related to EBITA margin implying that more the no of audit activities, the EBITA margin will decline and vice-versa. Nevertheless, the model here again lacks predictive power as it has R-square value of $1.9 \%$.

Individual Governance components on ROE - Impact and Analysis

Table 1.3 Impact of Individual Governance components on ROE

\begin{tabular}{|c|c|c|c|c|}
\hline \multicolumn{5}{|c|}{ Dependent Variable: ROE } \\
\hline \multicolumn{5}{|c|}{ Method: Panel Least Squares } \\
\hline \multicolumn{5}{|c|}{\begin{tabular}{l|l} 
Sample: 20062010 &
\end{tabular}} \\
\hline \multicolumn{5}{|c|}{ Cross-sections included: 163} \\
\hline \multicolumn{5}{|c|}{ Total panel (balanced) observations: 815} \\
\hline Variable & Coefficient & Std. Error & t-Statistic & Prob. \\
\hline $\mathrm{C}$ & 11.87639 & 8.934828 & 1.329224 & 0.1841 \\
\hline $\mathrm{BO}$ & -0.82281 & 0.555684 & -1.48072 & 0.1391 \\
\hline OW & 0.979504 & 0.302334 & 3.239809 & $0.0012 *$ \\
\hline $\mathrm{AC}$ & 1.372106 & 0.568719 & 2.412627 & $0.0161 *$ \\
\hline $\mathrm{RC}$ & 0.305323 & 0.186817 & 1.634343 & 0.1026 \\
\hline $\mathrm{CG}$ & -0.26118 & 0.149324 & -1.74911 & 0.0807 \\
\hline R-squared & 0.024402 & \multicolumn{2}{|c|}{ Mean dependent var } & 25.18676 \\
\hline Adjusted R-squared & 0.018372 & \multicolumn{2}{|c|}{ S.D. dependent var } & 20.70335 \\
\hline S.E. of regression & 20.51229 & \multicolumn{2}{|c|}{ Akaike info criterion } & 8.88726 \\
\hline Sum squared resid & 340390.1 & \multicolumn{2}{|c|}{ Schwarz criterion } & 8.921885 \\
\hline Log likelihood & -3615.56 & \multicolumn{2}{|c|}{ Hannan-Quinn criter. } & 8.90055 \\
\hline F-statistic & 4.046955 & \multicolumn{2}{|c|}{ Durbin-Watson stat } & 0.47984 \\
\hline Prob(F-statistic) & 0.001237 & & & \\
\hline
\end{tabular}

* and $* *$ indicate significance at $1 \%$ and $5 \%$ level of confidence. 
Table 1.3 reports explanatory power of the corporate governance variables of the Return on Equity. Both Audit committee and Ownership structure share a positive relationship with ROE at $1 \%$ level of significance. As both the variables are part of the monitoring mechanism of the agency theory of governance, the significance of the coefficients indicates that stronger monitoring will improve the return on equity and slack monitoring will result in lesser return on equity. But the model in explaining such relationship lacks predictive power as it has a $\mathrm{R}$ - squared value of $2.4 \%$.

\section{Individual Governance components on Sales Growth - Impact and Analysis}

Table 1.4 Impact of Individual Governance components on Sales Growth

\begin{tabular}{|c|c|c|c|c|}
\hline \multicolumn{5}{|c|}{ Dependent Variable: SG } \\
\hline \multicolumn{5}{|c|}{ Method: Panel Least Squares } \\
\hline \multicolumn{5}{|c|}{\begin{tabular}{|l|l|} 
Sample: 20062010 & \\
\end{tabular}} \\
\hline \multicolumn{5}{|c|}{ Cross-sections included: 163} \\
\hline \multicolumn{5}{|c|}{ Total panel (balanced) observations: 815} \\
\hline Variable & Coefficient & Std. Error & t-Statistic & Prob. \\
\hline $\mathrm{C}$ & 74.63557 & 19.92573 & 3.745688 & $0.0002 *$ \\
\hline $\mathrm{BO}$ & -3.77717 & 1.239242 & -3.04797 & $0.0024^{*}$ \\
\hline OW & -0.15533 & 0.674241 & -0.23038 & 0.8179 \\
\hline $\mathrm{AC}$ & -0.51935 & 1.268311 & -0.40948 & 0.6823 \\
\hline $\mathrm{RC}$ & 0.253054 & 0.416625 & 0.607392 & 0.5438 \\
\hline $\mathrm{CG}$ & -0.05825 & 0.33301 & -0.17492 & 0.8612 \\
\hline R-squared & 0.013265 & \multicolumn{2}{|c|}{ Mean dependent var } & 26.53041 \\
\hline Adjusted R-squared & 0.007167 & \multicolumn{2}{|c|}{ S.D. dependent var } & 45.90966 \\
\hline S.E. of regression & 45.74486 & \multicolumn{2}{|c|}{ Akaike info criterion } & 10.49137 \\
\hline Sum squared resid & 1692907 & \multicolumn{2}{|c|}{ Schwarz criterion } & 10.526 \\
\hline Log likelihood & -4269.23 & \multicolumn{2}{|c|}{ Hannan-Quinn criter. } & 10.50466 \\
\hline F-statistic & 2.17514 & \multicolumn{2}{|c|}{ Durbin-Watson stat } & 1.649108 \\
\hline Prob(F-statistic) & 0.055 & & & \\
\hline
\end{tabular}

* and ** indicate significance at $1 \%$ and $5 \%$ level of confidence.

In Table 1.4, none other except Board as governance variable shares a significant predictive relationship with Sales growth as a measure of performance of the firms. Though the relationship is negative it is significant. It indicates that sales will decline due to bigger size of the Board, the reason being decision making process gets delayed larger board. Again here also the predictive power of the model is not significant as indicated by the smaller R-square value of $1.3 \%$.

Individual Governance components on Dividend Payout Ratio Impact and Analysis

Table 1.5 Impact of Individual Governance components on Dividend Payout Ratio

\begin{tabular}{|c|c|c|c|c|}
\hline \multicolumn{5}{|c|}{ Dependent Variable: DP } \\
\hline \multicolumn{5}{|c|}{ Method: Panel Least Squares } \\
\hline \multicolumn{5}{|c|}{\begin{tabular}{l|l|} 
Sample: 20062010 & \\
\end{tabular}} \\
\hline \multicolumn{5}{|c|}{ Cross-sections included: 163} \\
\hline \multicolumn{5}{|c|}{ Total panel (balanced) observations: 815} \\
\hline Variable & Coefficient & Std. Error & t-Statistic & Prob. \\
\hline $\mathrm{C}$ & 16.48814 & 8.561643 & 1.925815 & $0.0545^{*}$ \\
\hline $\mathrm{BO}$ & -0.77222 & 0.532475 & -1.45025 & 0.1474 \\
\hline OW & 0.022154 & 0.289706 & 0.076471 & 0.9391 \\
\hline $\mathrm{AC}$ & 1.44101 & 0.544965 & 2.644226 & $0.0083^{*}$ \\
\hline $\mathrm{RC}$ & -0.12779 & 0.179014 & -0.71385 & 0.4755 \\
\hline $\mathrm{CG}$ & -0.09942 & 0.143087 & -0.69482 & 0.4874 \\
\hline R-squared & 0.010415 & \multicolumn{2}{|c|}{ Mean dependent var } & 24.93432 \\
\hline Adjusted R-squared & 0.004299 & \multicolumn{2}{|c|}{ S.D. dependent var } & 19.69793 \\
\hline S.E. of regression & 19.65555 & \multicolumn{2}{|c|}{ Akaike info criterion } & 8.801931 \\
\hline Sum squared resid & 312549.5 & \multicolumn{2}{|c|}{ Schwarz criterion } & 8.836556 \\
\hline Log likelihood & -3580.79 & \multicolumn{2}{|c|}{ Hannan-Quinn criter. } & 8.81522 \\
\hline F-statistic & 1.702859 & \multicolumn{2}{|c|}{ Durbin-Watson stat } & 0.743529 \\
\hline Prob(F-statistic) & 0.131432 & & & \\
\hline
\end{tabular}

* and ** indicate significance at $1 \%$ and $5 \%$ level of confidence.

The Table-1.5 reports the impact of governance explanatory variables on Dividend Payout. Only Audit committee explains the dividend payout. That means frequent audit activities result in more dividend payout. But again the model lacks explanatory power with a R- squared value of $1 \%$. We can conclude that the Ordinary Least Square model in the aforementioned multivariate regression analysis fails to carry significant predictive power. Further, it assumes that all the firm are homogenous even through the presence of heterogeneity is in cross sectional series. 
Thus for appropriate model to be applied for the multivariate analysis, we have applied Hausman Test with the null hypothesis that the random effect is applicable and alternative hypothesis is application of fixed effect model. The results are reported in the Table 1.6 are per which we cannot reject the null hypothesis of the application of random effect model for our study of the impact of the different facets of governance on performance variables of the firm.

\section{Application of Hausman Test \& Its Results:}

Table 1.6 Hausman Test Result

\begin{tabular}{|l|l|l|l|l|}
\hline Hausman Test & \multicolumn{5}{l|}{} \\
\hline Dependent Variable & Chi-Sq. Statistic & D F. & Prob. & Model \\
\hline P/B Ratio & 1.140132 & 5 & 0.9505 & Random Effect \\
\hline EBITDA Margin & 5.669088 & 5 & 0.3398 & Random Effect \\
\hline ROE & 7.02094 & 5 & 0.2191 & Random Effect \\
\hline Sales Growth & 0.612991 & 5 & 0.9874 & Random Effect \\
\hline Payout Ratio & 2.326241 & 5 & 0.8024 & Random Effect \\
\hline
\end{tabular}

The results of Panel data analysis are reported in Table 1.7 through Table 1.11 .

Individual Governance Components - Panel Data Analysis

Table1.7 Impact of Individual Governance components on P/B Ratio - Panel Data Analysis

\begin{tabular}{|c|c|c|c|c|}
\hline \multicolumn{5}{|c|}{\begin{tabular}{l|l} 
Dependent Variable: PB & \\
\end{tabular}} \\
\hline \multicolumn{5}{|c|}{ Method: Panel EGLS (Cross-section random effects) } \\
\hline \multicolumn{5}{|c|}{\begin{tabular}{|l|l|l} 
Sample: 20062010 & & \\
\end{tabular}} \\
\hline \multicolumn{5}{|c|}{ Cross-sections included: 163} \\
\hline \multicolumn{5}{|c|}{ Total panel (balanced) observations: 815} \\
\hline \multicolumn{5}{|c|}{ Swamy and Arora estimator of component variances } \\
\hline Variable & Coefficient & Std. Error & t-Statistic & Prob. \\
\hline $\mathrm{C}$ & 9.515971 & 5.593683 & 1.701199 & $0.0893 * * *$ \\
\hline $\mathrm{BO}$ & -0.63848 & 0.303149 & -2.10616 & $0.0355^{* *}$ \\
\hline OW & 0.374095 & 0.217301 & 1.721555 & $0.0855^{* * *}$ \\
\hline $\mathrm{AC}$ & 0.185547 & 0.359085 & 0.516722 & 0.6055 \\
\hline $\mathrm{RC}$ & 0.096045 & 0.127218 & 0.754963 & 0.4505 \\
\hline \multirow[t]{3}{*}{$\mathrm{CG}$} & -0.18945 & 0.104378 & -1.81503 & $0.0699 * * *$ \\
\hline & \multicolumn{3}{|c|}{ Effects Specification } & \\
\hline & & & S.D. & Rho \\
\hline \multicolumn{3}{|l|}{ Cross-section random } & 5.923521 & 0.4005 \\
\hline \multicolumn{3}{|l|}{ Idiosyncratic random } & 7.247871 & 0.5995 \\
\hline & \multicolumn{2}{|c|}{ Weighted Statistics } & & \\
\hline R-squared & 0.009479 & \multicolumn{2}{|l|}{ Mean dependent var } & 2.613002 \\
\hline Adjusted R-squared & 0.003357 & \multicolumn{2}{|l|}{ S.D. dependent var } & 7.242726 \\
\hline S.E. of regression & 7.23056 & \multicolumn{2}{|l|}{ Sum squared resid } & 42295.32 \\
\hline F-statistic & 1.548307 & \multicolumn{2}{|l|}{ Durbin-Watson stat } & 1.739815 \\
\hline \multirow[t]{2}{*}{ Prob(F-statistic) } & 0.172418 & & & \\
\hline & \multicolumn{3}{|c|}{ Unweighted Statistics } & \\
\hline R-squared & 0.022135 & \multicolumn{2}{|l|}{ Mean dependent var } & 5.443399 \\
\hline Sum squared resid & 69897.84 & \multicolumn{2}{|l|}{ Durbin-Watson stat } & 1.052765 \\
\hline
\end{tabular}

$*$ ** and $* * *$ indicate significance at $1 \%, 5 \%$ and $10 \%$ level of confidence.

Table 1.7 reports impact of five corporate governance variables on Price to Book ratio. Board impacts negatively to Price to Book ratio which is significant at 5\% level of confidence. On the other hand ownership and governance committee impacts positively to PB ratio which is significant at $10 \%$ confidence level. Further, PB is not explained by other governance factors like audit committee and remuneration committee.

Table 1.8 Impact of Individual Governance components on EBITDA Margin - Panel Data Analysis

\begin{tabular}{|c|c|c|c|c|}
\hline \multicolumn{5}{|c|}{\begin{tabular}{|l|l|} 
Dependent Variable: EM & \\
\end{tabular}} \\
\hline \multicolumn{5}{|c|}{ Method: Panel EGLS (Cross-section random effects) } \\
\hline \multicolumn{5}{|c|}{\begin{tabular}{l|l|l} 
Sample: 20062010 & & \\
\end{tabular}} \\
\hline \multicolumn{5}{|c|}{ Cross-sections included: 163} \\
\hline \multicolumn{5}{|c|}{ Total panel (balanced) observations: 815} \\
\hline \multicolumn{5}{|c|}{ Swamy and Arora estimator of component variances } \\
\hline Variable & Coefficient & Std. Error & t-Statistic & Prob. \\
\hline $\mathrm{C}$ & 29.9745 & 8.156984 & 3.674704 & $0.0003^{*}$ \\
\hline $\mathrm{BO}$ & 0.302232 & 0.32218 & 0.938083 & 0.3485 \\
\hline OW & -0.34848 & 0.654025 & -0.53282 & 0.5943 \\
\hline $\mathrm{AC}$ & 0.068707 & 0.495183 & 0.138751 & 0.8897 \\
\hline $\mathrm{RC}$ & 0.278271 & 0.2259 & 1.231832 & 0.2184 \\
\hline \multirow[t]{2}{*}{$\mathrm{CG}$} & 0.188402 & 0.237972 & 0.791697 & 0.4288 \\
\hline & \multicolumn{3}{|c|}{ Effects Specification } & \\
\hline
\end{tabular}


Corporate Governance and Performance of Indian Companies: Case Study

\begin{tabular}{|c|c|c|c|c|}
\hline & & & S.D. & Rho \\
\hline \multicolumn{3}{|l|}{ Cross-section random } & 27.74943 & 0.9561 \\
\hline \multicolumn{3}{|l|}{ Idiosyncratic random } & 5.947734 & 0.0439 \\
\hline & Weighted & & & \\
\hline R-squared & 0.004341 & \multicolumn{2}{|l|}{ Mean dependent var } & 3.587529 \\
\hline Adjusted R-squared & -0.00181 & \multicolumn{2}{|l|}{ S.D. dependent var } & 5.944809 \\
\hline S.E. of regression & 5.950194 & \multicolumn{2}{|l|}{ Sum squared resid } & 28642.49 \\
\hline F-statistic & 0.705472 & \multicolumn{2}{|l|}{ Durbin-Watson stat } & 1.195139 \\
\hline \multirow[t]{2}{*}{ Prob(F-statistic) } & 0.619426 & & & \\
\hline & \multicolumn{3}{|c|}{ Unweighted Statistics } & \\
\hline R-squared & 0.002868 & \multicolumn{2}{|l|}{ Mean dependent var } & 37.59837 \\
\hline Sum squared resid & 645480.7 & \multicolumn{2}{|l|}{ Durbin-Watson stat } & 0.053033 \\
\hline
\end{tabular}

$*, * *$ and $* * *$ indicate significance at $1 \%, 5 \%$ and $10 \%$ level of confidence.

As reported in Table 1.8, governance does not contribute EBITA margin of the firms. The reported results are not statistically significant.

Table 1.9 Impact of Individual Governance components on ROE - Panel Data Analysis

\begin{tabular}{|c|c|c|c|c|}
\hline \multicolumn{5}{|c|}{ Dependent Variable: ROE } \\
\hline \multicolumn{5}{|c|}{ Method: Panel EGLS (Cross-section random effects) } \\
\hline \multicolumn{5}{|c|}{$\begin{array}{l}\text { Sample: } 20062010 \\
\end{array}$} \\
\hline \multicolumn{5}{|c|}{ Cross-sections included: 163} \\
\hline \multicolumn{5}{|c|}{ Total panel (balanced) observations: 815} \\
\hline \multicolumn{5}{|c|}{ Swamy and Arora estimator of component variances } \\
\hline Variable & Coefficient & Std. Error & t-Statistic & Prob. \\
\hline $\mathrm{C}$ & 37.31131 & 12.24875 & 3.046132 & $0.0024 *$ \\
\hline $\mathrm{BO}$ & -1.78081 & 0.609441 & -2.92203 & $0.0036^{*}$ \\
\hline OW & 0.897127 & 0.535073 & 1.676645 & $0.094 * * *$ \\
\hline $\mathrm{AC}$ & 0.291251 & 0.787011 & 0.370072 & 0.7114 \\
\hline $\mathrm{RC}$ & 0.317166 & 0.295789 & 1.07227 & 0.2839 \\
\hline \multirow[t]{3}{*}{ CG } & -0.25855 & 0.251119 & -1.0296 & 0.3035 \\
\hline & \multicolumn{3}{|c|}{ Effects Specification } & \\
\hline & & & S.D. & Rho \\
\hline \multicolumn{2}{|l|}{ Cross-section random } & \multicolumn{2}{|l|}{16.07927} & 0.6061 \\
\hline \multicolumn{2}{|l|}{ Idiosyncratic random } & \multicolumn{2}{|l|}{12.96307} & 0.3939 \\
\hline & \multicolumn{3}{|c|}{ Weighted Statistics } & \\
\hline R-squared & 0.015116 & \multicolumn{2}{|l|}{ Mean dependent var } & 8.542624 \\
\hline Adjusted R-squared & 0.009029 & \multicolumn{2}{|l|}{ S.D. dependent var } & 13.03824 \\
\hline S.E. of regression & 12.97925 & \multirow{2}{*}{\multicolumn{2}{|c|}{$\begin{array}{l}\text { Sum squared resid } \\
\text { Durbin-Watson stat }\end{array}$}} & 136284.8 \\
\hline F-statistic & 2.483278 & & & 1.191908 \\
\hline \multirow[t]{2}{*}{ Prob(F-statistic) } & 0.030356 & \multicolumn{2}{|l|}{ Durbin-Watson stat } & \\
\hline & \multicolumn{3}{|c|}{ Unweighted Statistics } & \\
\hline R-squared & 0.013967 & \multicolumn{2}{|l|}{ Mean dependent var } & 25.18676 \\
\hline Sum squared resid & 344030.8 & \multicolumn{2}{|l|}{ Durbin-Watson stat } & 0.472164 \\
\hline
\end{tabular}

* ** and $* * *$ indicate significance at $1 \%, 5 \%$ and $10 \%$ level of confidence.

Table 1.9 shows that Return on Equity is negatively affected by the Board which is statistically significant at $1 \%$ confidence level and positively impacted by the ownership structure of the firms. But since the $\mathrm{R}$-squared value is only $1.5 \%$, the model lacks explanatory power.

Table 1.10 Impact of Individual Governance components on Sales Growth - Panel Data Analysis

\begin{tabular}{|c|c|c|c|c|}
\hline \multicolumn{2}{|c|}{ Dependent Variable: SG } & & & \\
\hline \multicolumn{5}{|c|}{ Method: Panel EGLS (Cross-section random effects) } \\
\hline \multicolumn{5}{|c|}{\begin{tabular}{l|l|l|} 
Sample: 20062010 & & \\
\end{tabular}} \\
\hline \multicolumn{5}{|c|}{ Cross-sections included: 163} \\
\hline \multicolumn{5}{|c|}{ Total panel (balanced) observations: 815} \\
\hline \multicolumn{5}{|c|}{ Swamy and Arora estimator of component variances } \\
\hline Variable & Coefficient & Std. Error & t-Statistic & Prob. \\
\hline $\mathrm{C}$ & 77.28332 & 23.44246 & 3.296724 & $0.001 *$ \\
\hline $\mathrm{BO}$ & -3.99422 & 1.402494 & -2.84794 & $0.0045^{*}$ \\
\hline OW & -0.14213 & 0.821294 & -0.17305 & 0.8627 \\
\hline $\mathrm{AC}$ & -0.52116 & 1.496861 & -0.34817 & 0.7278 \\
\hline $\mathrm{RC}$ & 0.248959 & 0.501364 & 0.496564 & 0.6196 \\
\hline \multirow[t]{3}{*}{$\mathrm{CG}$} & -0.07836 & 0.402637 & -0.19462 & 0.8457 \\
\hline & \multicolumn{3}{|c|}{ Effects Specification } & \\
\hline & & & S.D. & Rho \\
\hline \multicolumn{3}{|l|}{ Cross-section random } & 16.0254 & 0.1217 \\
\hline \multicolumn{3}{|l|}{ Idiosyncratic random } & 43.04946 & 0.8783 \\
\hline
\end{tabular}


Corporate Governance and Performance of Indian Companies: Case Study

\begin{tabular}{|l|l|l|l|l|}
\hline & \multicolumn{2}{|l|}{ Weighted Statistics } & \\
\hline R-squared & 0.011339 & Mean dependent var & 20.3907 \\
\hline Adjusted R-squared & 0.005229 & \multicolumn{2}{|l|}{ S.D. dependent var } & 43.04526 \\
\hline S.E. of regression & 42.93258 & \multicolumn{2}{|l|}{ Sum squared resid } & 1491154 \\
\hline F-statistic & 1.855685 & \multicolumn{2}{|l|}{ Durbin-Watson stat } & 1.872138 \\
\hline Prob(F-statistic) & 0.099767 & & \\
\hline & Unweighted Statistics & \\
\hline R-squared & 0.013224 & \multicolumn{2}{|l|}{ Mean dependent var } & 26.53041 \\
\hline Sum squared resid & 1692978 & \multicolumn{2}{|l|}{ Durbin-Watson stat } & 1.648955 \\
\hline
\end{tabular}

* ** and $* * *$ indicate significance at $1 \%, 5 \%$ and $10 \%$ level of confidence.

None other governance factors except Board impacts sales growth of the firms as per the results reported in Table 1.10. The size of the Board is negatively related with sales growth that means when size of the Board increases, growth in sales declines and vice-versa.

Table1.11 Impact of Individual Governance components on Payout Ratio - Panel Data Analysis

\begin{tabular}{|c|c|c|c|c|}
\hline \multicolumn{5}{|c|}{ Dependent Variable: DP } \\
\hline \multicolumn{5}{|c|}{ Method: Panel EGLS (Cross-section random effects) } \\
\hline \multicolumn{5}{|c|}{\begin{tabular}{|l|l|} 
Sample: 20062010 & \\
\end{tabular}} \\
\hline \multicolumn{5}{|c|}{ Cross-sections included: 163} \\
\hline \multicolumn{5}{|c|}{ Total panel (balanced) observations: 815} \\
\hline \multicolumn{5}{|c|}{ Swamy and Arora estimator of component variances } \\
\hline Variable & Coefficient & Std. Error & t-Statistic & Prob. \\
\hline $\mathrm{C}$ & 10.93466 & 11.93802 & 0.915953 & 0.36 \\
\hline $\mathrm{BO}$ & -1.07671 & 0.612882 & -1.75679 & $0.0793^{* * * *}$ \\
\hline $\mathrm{OW}$ & 0.086318 & 0.49749 & 0.173507 & 0.8623 \\
\hline $\mathrm{AC}$ & 2.039589 & 0.767168 & 2.658596 & $0.008^{*}$ \\
\hline $\mathrm{RC}$ & -0.01038 & 0.281771 & -0.03683 & 0.9706 \\
\hline \multirow[t]{3}{*}{$\mathrm{CG}$} & -0.15183 & 0.235721 & -0.6441 & 0.5197 \\
\hline & \multicolumn{3}{|c|}{ Effects Specification } & \\
\hline & & & S.D. & Rho \\
\hline \multicolumn{3}{|l|}{ Cross-section random } & 14.49112 & 0.5345 \\
\hline \multicolumn{3}{|l|}{ Idiosyncratic random } & 13.52399 & 0.4655 \\
\hline & \multicolumn{3}{|c|}{\begin{tabular}{|l|l} 
Weighted Statistics & \\
\end{tabular}} & \\
\hline R-squared & 0.011054 & \multicolumn{2}{|c|}{ Mean dependent var } & 9.603846 \\
\hline Adjusted R-squared & 0.004942 & \multicolumn{2}{|c|}{ S.D. dependent var } & 13.53511 \\
\hline S.E. of regression & 13.50162 & \multicolumn{2}{|c|}{ Sum squared resid } & 147475.7 \\
\hline F-statistic & 1.808473 & \multicolumn{2}{|c|}{ Durbin-Watson stat } & 1.57482 \\
\hline \multirow[t]{2}{*}{ Prob(F-statistic) } & 0.108712 & & & \\
\hline & \multicolumn{3}{|c|}{ Unweighted Statistics } & \\
\hline R-squared & 0.008338 & \multicolumn{2}{|c|}{ Mean dependent var } & 24.93432 \\
\hline Sum squared resid & 313205.4 & \multicolumn{2}{|c|}{ Durbin-Watson stat } & 0.741519 \\
\hline
\end{tabular}

$*, * *$ and $* * *$ indicate significance at $1 \%, 5 \%$ and $10 \%$ level of confidence.

In Table 1.11, it is observed that Dividend payout ratio is negatively related to size of the Board and positively related with the audit committee at statistical significance level of $10 \%$ and $1 \%$ respectively. More the activities of the audit committee, one can expect a better dividend payout ratio. However, increase in Board size results in lesser dividend payout ratio. Nevertheless, the model lack significant explanatory power as indicated by the R-squared value of $1.1 \%$.

\section{Impact of Individual Governance Components on Firm Performance}

The study investigates the relationship between various facets of corporate governance and six different performance variables independently. In order to draw a reliable conclusion, a multivariate regression framework is used. The analysis of the impact of the five different constituents of corporate governance (Board Process and Structure, Ownership Structure, Audit committee, Remuneration Committee and Grievance Committee) on Price to Book value ratio exhibits that the Price to Book ratio is impacted by three governance facets like Board process and Structure, Ownership and Governance committee. A negative correlation between firm value and the size of a firm's board of directors supports the findings of many of the previous studies.

A subsequent analysis of the impact of five governance variables on firms' EBITA margin reveals that both Board structure and process and Remuneration Committee share a positive and significant predictive relationship with firms' EBITA margin while the audit committee negatively related to EBITA margin implying that more the no of audit activities, the EBITA margin will decline and vice-versa. Similarly an analysis of the impact of corporate governance variables of the Return on Equity highlights that both Audit committee and Ownership structure share an influencing relationship with ROE. As both the variables are part of the 
monitoring mechanism of the agency theory of governance, the significance of the coefficients indicates that stronger monitoring will improve the return on equity and slack monitoring will result in lesser return on equity. A cursory look at the impact of individual governance facets portrays that none other than Board Process and Structure shares a significant predictive relationship with Sales growth as a measure of performance of the firms. Though the relationship is negative it is significant. It indicates that a higher growth in sales is hampered due to bigger size of the Board, more and more meetings etc. The possible reason may be the delay in decision making process that is prevalent in a larger board. In case of Dividend Payout ratio, it's only the Audit committee that explains the dividend payout signifying that a stringent audit activities result in more dividend payout.

The above results obtained through Ordinary Least Square model in the aforementioned multivariate regression analysis may have some limitation as the model assumes that the entire firm are homogenous even through the presence of heterogeneity is in cross sectional series. Thus a further verification through a panel data analysis is thought to be appropriate for the multivariate analysis. In order to specify the panel regression model, we have applied Hausman Test with the null hypothesis that the random effect is applicable and alternative hypothesis is application of fixed effect model. The result of Hausman Test favoured the application of random effect model for the study.

The panel result reports the impact of three out of five corporate governance variables on Price to Book ratio. While the Board Process and Structure impacts Price to Book ratio negatively, ownership structure and governance committee impacts the ratio positively. PB ratio is not explained by other governance factors like audit committee and remuneration committee. Interestingly none of the governance facets has a significant influence on the EBITA margin of the firms. Another measure of performance, Return on Equity is found to be negatively affected by the Board Process and Structure and positively impacted by the ownership structure of the firms. Consistent with the OLS result, the sales growths of the firms are not influenced by any governance variable other than Board Process and Structure. The size of the Board is negatively related with sales growth. The panel data analysis also reveals that Dividend payout ratio is negatively influenced by the Board Process and Structure and positively related with the audit committee. More the activities of the audit committee, one can expect a better dividend payout ratio. However, increase in Board size results in lesser dividend payout ratio.

\section{Conclusion}

Summarizing the results of the analysis of individual impact of governance facets on performance variables under a random effect model, no facets of governance impacts the EBITDA margin. Further, Board structure impacts negatively to the performance in terms of P/B ratio, Return on Equity, Sales growth and Dividend payout ratio. It shows that though it is good to have more no of board meetings and attendance, but presence of independent directors and CEO duality impacts the performance negatively and significantly. However, positive performance in terms of $\mathrm{P} / \mathrm{B}$ ratio, $\mathrm{ROE}$, and dividend payout ratio contributed by ownership, grievance committee and audit committee.

\section{Reference}

[1]. Jensen and Meckling (1976)Theory of a managerial Behaviour , Agency Costs and Ownership Structure, Journal of Financial Economics , 3(1), $305-360$

[2]. Johnson, Boone, Breach, Friedman (2000)Corporate Governance in an ASIAN Financial Crisis, Journal of Financial Economics , $58,141-186$

[3]. Yermack, 1996 Higher Market Valuation of companies with a small board of Directors, Journal of Financial Economics , 40 , 185 211

[4]. Brown, Robinson, Caylor (2004), Corporate Governance and firm Performance.www.issproxy.com

[5]. Back, Kang \& Park (2004)Corporate Governance and firm value :Evidence from the Korean Financial crisis, Journan of Financial Economics, Vol 71, $265-313$

[6]. Drobetz et.al., (2004) Corporate Governance and Expected Stock Returns : Evidence from germany , European Financial Management, Vol 10, No 2, 267 - 293

[7]. Short et el (1999) Managerial Ownership and performance of firms : Evidence from U K, Journal of Corporate Finance , Vol 05 , $79-101$

[8]. Lipton and Lorsch, 1992 A modest proposal for improved corporate governance, Business Lawyer , 48 , 59 - 77

[9]. Rosenstein and Wyatt (1990) Outside Directors, Board independence and shareholder Wealth, Journal of Financial Economics , 26 , 175 - 191

[10]. Ananya Mukherjee Reed (2002), “ Corporate Governance Reforms in India” Journal of Business Ethics 37 : PP 249 - 268 , 2002

[11]. Lipton and Lorsch (1992), A modest proposal for improved corporate governance , Business lawer , 48 , 59 - 77

[12]. Bernard S. Black \& Vikramaditya S. Khanna “ Can Corporate Governance Reforms Increase Firm's Market Values : Event Study Evidence from India" PP $01-34$

[13]. Kamala Gollakoti \& Vipin Gupta “ History , ownership forms and corporate governance in India” Journal of management History Vol 12 , No 2, 2006 PP $185-198$

[14]. Stijn Claessens \& Joseph P H Fan “ Corporate Governance in Asia : A Survey” International Review of Finance 3:2, 2002 , PP 73 $-103$ 
[15]. Kamala Gollakota, Vipin Gupta “History, Ownership forms and Corporate Governance in India” Journal of Management History Vol 12 No 2, 2006 PP 185 -198

[16]. Ajay Kumar Garg “Influence of Board Size and Independence on firm performance : A study of Indian firms” VIKALPA, volume 32 , No 3 , July - September 2007, PP $39-60$

[17]. Balatbat C, A naira , Taylor . L Stephen, Walter S Terry (2004), "Corporate Governance, Insider Ownership and Operating Performance of Australian IPO”, Accounting and Finance, Vol 44, PP $299-328$

[18]. Barnhart, S. W. and Rosenstein, S., 1998. Board composition, managerial ownership, and firm performance: an empirical analysis The Financial Review, vol. 33, 1-16

[19]. Bauer, R., Gunster, N. and Otten, R., 2003. Empirical evidence on corporate governance in Europe. Journal of Asset Management, forthcoming

[20]. Bernard Black. "The CG behavior and market value of Russian firms". Emerging market review, 2 (2001),89-108.

[21]. Bhagat S \& Black B (2002), "Board Independence and Long term performance", Journal of Corporation Law, 27, PP 1-12

[22]. Bhagat, S. and Black, B., 2002. The non-correlation between board independence and long-term firm performance. Journal of Corporation Law, vol. 27, No. 2, 231-273

[23]. Black, B., Jang, H. and Kim, W., 2002. Does corporate governance affect firm value? Evidence from Korea. Working paper, Stanford Law School, Korea University Business School, and KDI School of Public Policy and Management. 